\title{
Regulasi Emosi Secara Kognitif Guru dan Perilaku Antisosial Anak
}

\author{
Dema Yulianto ${ }^{1)}$, Hanggara Budi Utomo ${ }^{2)}$, dan Epritha Kurniawati ${ }^{3)}$ \\ ${ }^{1)}$ radendema@gmail.com \\ 2) hanggara@unpkediri.ac.id \\ 3) epritha@unpkediri.ac.id \\ Pendidikan Guru Pendidikan Anak Usia Dini \\ Fakultas Keguruan dan Ilmu Pendidikan \\ Universitas Nusantara PGRI Kediri 1,2,3
}

\begin{abstract}
Abstrak
Mengelola emosi dapat dilakukan dengan pendekatan kognitif dan perilaku. Pendekatan kognitif menjelaskan bahwa emosi yang dirasakan individu merupakan hasil dari penilaian terhadap situasi yang dihadapinya. Tujuan penelitian adalah untuk mengkaji pendekatan regulasi emosi secara kognitif guru dalam menghadapi perilaku anti sosial anak TK. Metode penelitian ini adalah studi pustaka dengan pendekatan kualitatif. Secara mendasar, studi pustaka terkait dengan kajian teoritis dan referensi lain yang berkaitan dengan nilai, budaya, dan norma yang berkembang pada situasi yang diteliti. Pendekatan regulasi emosi secara kognitif yang dapat dilakukan guru, antara lain: (1) guru dapat mengajarkan regulasi emosi anak dengan cara menanggapi emosi dan mengajarkan tentang emosi; (2) guru dapat memberikan bimbingan dalam kompetensi emosional dengan cara memberikan contoh emosi yang positif dan negatif, cara menanggapi emosi anak, dan memanifestasikan emosi; (3) guru dapat berinteraksi dengan anak, sambil mengidentifikasi emosi yang sering muncul pada diri anak-anak.
\end{abstract}

Kata Kunci: regulasi, emosi, kognitif, guru

\begin{abstract}
Emotional regulation can be done with cognitive and behavioral approaches. The cognitive approach explains that the emotions felt by individuals are the result of an assessment of the situation they are facing. The research objective was to describe and explore the approach to cognitive-emotional regulation of teachers in dealing with the anti-social behavior of kindergarten children. This research method is a literature study with a qualitative approach. Basically, the literature study is related to theoretical studies and other references related to values, culture, and norms that develop in the situation under study. The role of cognitive-emotional regulation that teachers can do, includes: (1) teachers can teach children's emotional regulation by responding to emotions and teaching about emotions; (2) teachers can provide guidance in emotional competence by giving examples of positive and negative emotions, how to respond to children's emotions, and manifest emotions; (3) teachers can interact with children while identifying emotions that often arise in children.
\end{abstract}

Keywords: regulation, emotion, cognitive, teacher 
Jurnal PINUS: Jurnal Penelitian Inovasi Pembelajaran, 6 (1), 2020, Dema Yulianto, Hanggara Budi Utomo, dan Epritha Kurniawati

\section{PENDAHULUAN}

Masalah perilaku antisosial yang dapat ditemui dalam kegiatan pembelajaran di Taman kanak-kanak (selanjutnya disingkat TK) adalah pada perilaku yang tidak patuh dan tempertantrum (amukan). Kepatuhan adalah melakukan apa yang diminta oleh orang lain (dalam hal ini orang tua atau guru) dengan tepat dan sesuai. Pertanyaan yang paling sering diajukan oleh orang tua maupun guru adalah, "bagaimana cara saya mendidik anak agar mau melakukan apa yang saya perintahkan?”. Adanya sikap penolakan pada anak-anak prasekolah terhadap lingkungan sosianya sesungguhnya adalah hal yang wajar dan menjadi bagian dari proses perkembangan alamiah. Anak-anak mulai tumbuh sebagai pribadi, memiliki keinginannya sendiri, dan memunculkan egonya. Anak mulai ingin membedakan dirinya dengan orang lain, dan sikap berbeda ini ditunjukkan anak dengan memunculkan sikap negativistik, misalnya bila orang lain menyuruhnya melakukan sesuatu, maka anak akan menolak.

Hal inilah yang kemudian di persepsi oleh orang dewasa sebagai tanda bahwa anak sudah berani membantah, sulit diatur, dan tidak patuh lagi. Salah satu faktor yang menjadi penyebab anak tidak patuh adalah kurangnya disiplin. Hal ini didukung oleh penelitian John (2011) yang menyatakan guru pada umumnya mengalami kesulitan untuk membuat anak disiplin dalam proses belajar, khususnya di kelas anak usia dini. Apabila hal ini tidak diatasi dapat mengakibatkan anak terbiasa dalam keadaan tidak disiplin sehingga mutu, proses dan hasil belajar menurun. Ada tiga permasalahan utama dalam hal kedisiplinan yang dihadapi di dalam kelas yaitu: anak sulit untuk menyimak guru saat menerangkan pelajaran, anak tidak mau mendengarkan perkataan guru (tidak patuh), dan anak tidak terbiasa berbicara dengan sopan, baik terhadap guru maupun terhadap teman (John, 2011).

Berdasarkan kajian yang dilakukan Yulianto, dkk (2019) bahwa anak sudah berani membantah, sulit diatur, dan tidak patuh lagi disebabkan karena anak kurang memiliki sikap prososial. Anak-anak banyak menghabiskan waktu dengan menonton acara televisi, menonton film-film anak dalam DVD dan bermain games dalam media teknologi. Bagi sebagian orangtua, yang terpenting adalah anaknya nyaman serta aman di rumah untuk duduk dan diam. Selain itu, berdasarkan hasil pengamatan peneliti didampingi oleh guru kelas secara langsung terhadap aktivitas anak ketika sedang bermain di kelas, anak jarang sekali untuk berbagi, bekerjasama, maupun bersikap toleransi terhadap sesama temannya.

Situasi dan kondisi yang penuh tekanan yang dialami guru dan dituntut untuk dapat mengenali setiap masalah dalam perkembangan anak prasekolah, berpotensi menimbulkan emosi-emosi negatif. Seperti halnya masalah gangguan perilaku antisosial dan gangguan emosi anak berupa tidak patuh dan temperamen juga dapat menimbulkan permasalahan di sekolah, sehingga guru mengeluh dan tidak sanggup menghadapi anak. Hal 
Jurnal PINUS: Jurnal Penelitian Inovasi Pembelajaran, 6 (1), 2020, Dema Yulianto, Hanggara Budi Utomo, dan Epritha Kurniawati

tersebut membuat guru cemas dan jengkel saat anak didiknya tidak patuh dan suka mengamuk. Guru mengungkapkan kecemasan dan kejengkelan dalam bentuk emosi verbal, dan mengungkapkan dalam bentuk teguran keras pada anak yang suka mengamuk. Merasa cemas sebagai guru dapat terjadi lebih buruk jika guru merasa tidak didukung dan merasa dikucilkan. Sisi yang lain, guru juga merupakan individu yang sangat teliti yang memiliki dorongan luar biasa untuk membantu orang lain, sehingga memberikan tekanan yang tidak realistis pada diri mereka sendiri. Kondisi tertekan ini menjadi stressor bagi Guru yang memiliki anak didik yang mengalami perilaku antisosial. Perasaan Guru yang mengeluh, jengkel atau marah, dan cemas ini termasuk dalam kategorisasi emosi negatif. Individu yang mengalami emosi negatif akibat situasi dan kondisi yang penuh tekanan mempunyai kesempatan yang lebih besar dalam merasakan manfaat dari penggunaan strategi regulasi emosi (Burgess, 2006). Menurut Sutton dan Wheatley (2003) bahwa emosi guru berpengaruh dengan kognisi siswa, motivasi, dan perilaku.

Menurut Gross (1998) bahwa terdapat pengaruh regulasi, antara lain: coping, mood regulation (pengaturan mood), Defenses (pertahanan), dan emotion regulation (Regulasi Emosi). Dalam regulasi emosi terdiri atas bagianbagian regulasi emosi, antara lain: kepribadian, klinis, kesehatan, biologi, kognitif, perkembangan, dan sosial (Gross, 1998). Regulasi emosi adalah usaha individu untuk mempengaruhi emosi yang mereka alami, dan bagaimana emosi ini dihayati dan diekspresikan (Gross dkk., 2007). Menurut penelitian Fried (2011) menyatakan bahwa emosi memiliki pengaruh yang signifikan pada pembelajaran dan karena sekolah adalah proses emosional, ada kalanya siswa dan guru perlu menerapkan strategi regulasi emosi di dalam kelas.

Mengelola emosi (regulasi emosi) dapat dilakukan dengan pendekatan kognitif dan perilaku (Gross, 2002). Pendekatan kognitif menjelaskan bahwa emosi yang dirasakan individu merupakan hasil dari penilaian terhadap situasi yang dihadapinya. Individu yang menilai situasi yang dihadapi sebagai sesuatu yang positif akan mengembangkan respons emosi yang positif pula, sebaliknya individu yang memberikan penilaian negatif terhadap situasi yang dihadapi akan mengembangkan emosi negatif pula. Berdasarkan penelitian yang dilakukan (Gross, 2002) individu yang memilih strategi antecedent-focused mempunyai fungsi interpersonal dan kesejahteraan yang lebih baik. Pada proses responsefocused berlangsung usaha untuk menekan ekspresi emosi (suppression), dimana strategi tersebut efektif untuk menurunkan ekspresi emosi negative tetapi memberikan efek samping yaitu menekan ekspresi positif dan tidak membantu mengurangi pengalaman negative. Proses ini membutuhkan usaha yang lebih untuk mengatur ekspresi emosi (Gross, 2002).

Tujuan penelitian yang ingin dikaji oleh peneliti adalah untuk mendeskripsikan dan mengeksplorasi 
Jurnal PINUS: Jurnal Penelitian Inovasi Pembelajaran, 6 (1), 2020, Dema Yulianto, Hanggara Budi Utomo, dan Epritha Kurniawati

pendekatan regulasi emosi secara kognitif guru dalam menghadapi perilaku anti sosial anak TK. Peneliti juga menghubungkan dengan sejarah teori dan penelitian regulasi emosi secara kognitif sebagai dasar dalam melakukan pendekatan regulasi emosi.

\section{METODE}

Metode penelitian ini adalah studi pustaka dengan pendekatan kualitatif. Secara mendasar, studi pustaka merupakan metode pengumpulan data yang terkait dengan kajian teoretis dan referensi lain yang berkaitan dengan nilai, budaya, dan norma yang berkembang pada situasi yang diteliti. Studi pustaka sangat penting dalam melakukan penelitian dan tidak terlepas dari literaturliteratur ilmiah (Sugiyono, 2017). Jenis studi pustaka yang dilakukan dalam penelitian ini adalah studi pustaka teknik simak dan catat, dengan prosedur mengumpulkan data dengan cara menggunakan buku elektronik, jurnal ilmiah, dan literatur ilmiah lainnya, kemudian mencatat dengan cara mengutip pendapat para ahli untuk memperkuat landasan teori penelitian.

\section{HASIL}

Penelusuran hasil studi pustaka seperti kajian yang dilakukan Gross dkk., (2007) dengan fokus percobaan regulasi dan aspek perilaku emosi dapat menurunkan emosi negatif, seperti: marah, sedih, dan cemas. Selain itu, dalam hubungan antara regulasi emosi dan aspek yang mempengaruhinya, sebenarnya regulasi emosi merupakan bagian dari pengaruh regulasi (Westen,
1994). Menurut Gross (1998) regulasi emosi terjadi bagaimana pengaruh individu terhadap emosi yang dimiliki, ketika memiliki emosi, dan bagaimana individu mengalami dan mengekspresikan emosi. Studi ini mengambil perspektif evolusioner dan ciri emosi dalam hal kecenderungan respon. Regulasi emosi didefinisikan dan dibedakan dari mengatasi, pengaturan atau regulasi mood, pertahanan, dan pengaruh regulasi. Dalam disiplin psikologi yang semakin khusus, bidang regulasi emosi melintasi batas-batas tradisional dan memberikan kesamaan.

Menurut model proses regulasi emosi, emosi dapat diatur di lima titik dalam proses generatif emosi: (a) pemilihan situasi, (b) modifikasi situasi, (c) penyebaran perhatian, (d) perubahan kognisi, dan (e) modulasi respons. Bidang regulasi emosi menjanjikan wawasan baru ke dalam pertanyaan kuno tentang bagaimana orang mengelola emosi mereka. Dalam regulasi emosi terdiri atas bagian-bagian regulasi emosi, antara lain: kepribadian, klinis, kesehatan, biologi, kognitif, perkembangan, dan sosial (Gross, 1998). Dimensi regulasi emosi secara kognitif menurut Garnefski dkk.,(2001), antara lain: self-blame, acceptance, rumination, positive refocusing, refocus on planning, positive reappraisal, putting into perspective, catastrophizing, blaming others.

\section{PEMBAHASAN}

Anak yang memasuki taman kanak-kanak mulai dituntut mengatasi ketergantungan pada orang tua atau 
Jurnal PINUS: Jurnal Penelitian Inovasi Pembelajaran, 6 (1), 2020, Dema Yulianto, Hanggara Budi Utomo, dan Epritha Kurniawati

pengasuhnya. Anak mulai menolong dirinya sendiri seperti menggunakan toilet, memakai baju, dan sepatu sendiri. Inisiatif dari anak sangat diperlukan, karena anak membutuhkan peran orangorang sekelilingnya untuk mengambil inisiatif bagi dirinya. Ketidakmandirian seorang anak identik dengan sikap bergantung yang terlalu berlebihan pada orang-orang di sekitarnya. Anak seharusnya sudah mulai dapat mengurus dirinya sendiri, serta kebebasan menjadi manusia dewasa pada saat nantinya.

Keterampilan pengaturan diri dini anak-anak sangat penting untuk kesejahteraan sosial-emosional dan prestasi akademik anak nantinya. Beberapa manfaat untuk identifikasi dan pengembangan lebih lanjut dari tindakan regulasi diri anak yang valid dan dapat diandalkan, khususnya, sebagaimana dinyatakan dalam konteks kelas. Ada potensi guru untuk mengembangkan regulasi emosi dikaitkan dengan perilaku anti sosial anak-anak yang dapat secara langsung dan spesifik terkait dengan apa yang dilakukan seorang guru di kelas, antara lain: guru memahami bahwa keterampilan pengaturan diri sangat penting untuk aspek lain dari pembelajaran dan pengembangan anak (misalnya, guru memaksimalkan kapasitas pengaturan diri anak selama belajar); 2) guru mendorong anak supaya lebih mampu mengatur diri sendiri selama situasi yang menantang (misalnya, guru mengubah lingkungan belajar dan selanjutnya mendukung keberadaan pembelajaran dengan terlebih dahulu memahami emosi guru sendiri, selanjutnya memahami emosi anak).
Penelitian tentang regulasi emosi sebenarnya berawal dari penelitian tentang emosi. Menurut Strongman (2003) penelitian emosi sudah diterapkan oleh Darwin pada tahun 1872 yang meneliti bagaimana ekspresi emosi manusia dan binatang. Dalam penelitian regulasi emosi, berakar pada studi mekanisme pertahanan, stress psikologi dan coping, teori kelekatan, teori emosi. Selanjutnya berkembang ke konstruksi literatur perkembangan kemudian berkembang tentang studi regulasi emosi orang dewasa (Strongman, 2003). Makna regulasi emosi adalah krusial ambigu, karena mungkin merujuk sama baiknya bagaimana emosi mengatur sesuatu yang lain, seperti pikiran, fisiologi, atau perilaku (regulasi emosi) atau bagaimana emosi itu sendiri diatur (regulasi emosi). Namun, jika fungsi utama dari emosi adalah koordinasi respons sistem (Levenson, 1999), perasaan pertama regulasi emosi adalah berbeda dengan emosi.

Selanjutnya, penelitian tentang regulasi emosi secara kognitif dilakukan oleh Thompson, Ross\& Calkins (1996) yang membahas regulasi bagaimana emosi pada anak-anak yang berisiko, dapat secara bersamaan mendorong kedua ketahanan dan kerentanan dengan mempertimbangkan bagaimana emosi dikelola ketika anak-anak (a) hidup dengan orangtua yang depresi, (b) saksi atau pengalaman kekerasan dalam rumah tangga, atau (c) yang temperamental terhambat ketika menghadapi tantangan baru. Garnefski dkk., (2001) mengkaji tentang masalah emosi dan regulasi emosi secara kognitif yang dilakukan di 
Jurnal PINUS: Jurnal Penelitian Inovasi Pembelajaran, 6 (1), 2020, Dema Yulianto, Hanggara Budi Utomo, dan Epritha Kurniawati

tiga sekolah negeri yang berbeda dengan cara siswa mengisi kuesioner selama jam sekolah dibawah pengawasan guru dan dua mahasiswa psikologi. Teknik analisis menggunakan The CERQ Symptom Check List (SCL Derogatis). Hasil penelitian menunjukkan bahwa strategi coping kognitif atau regulasi emosi secara kognitif ditemukan memainkan peran penting dalam hubungan antara pengalaman peristiwa kehidupan negatif dan pelaporan gejala depresi dan kecemasan. Hasil tersebut senada dengan kajian Gross (2002) yang meneliti tentang keterkaitan regulasi emosi dengan afektif, kognitif, dan konsekuensi sosial. Salah satu tantangan besar kehidupan adalah berhasil mengatur emosi. Penelitian tersebut menemukan bahwa dimensi penilaian kembali lebih efektif daripada penekanan. Penilaian kembali menurunkan pengalaman emosi dan ekspresi perilaku, dan tidak berdampak pada memori. Sebaliknya, penekanan menurunkan ekspresi perilaku, namun gagal untuk mengurangi pengalaman emosi, dan benar-benar mengganggu memori. Penekanan juga meningkatkan fisiologis menanggapi untuk penekan dan mitra sosial individu.

Menurut Sutton dan Wheatley (2003) yang meneliti berkaitan dengan multi komponen dari emosi (positif atau negatif) guru berpengaruh dengan kognisi siswa, motivasi, dan perilaku. Penelitian Sutton (2004)membahas dua pertanyaan, yaitu: apa tujuan guru melakukan regulasi emosional mereka sendiri, dan strategi apa yang guru gunakan untuk mengatur emosi mereka sendiri. Guru percaya bahwa mengatur emosi mereka bertujuan untuk efektivitas mengajar dan untuk mengetahui apakah sesuai dengan gambaran emosi ideal dari seorang guru. Guru menggunakan berbagai strategi regulasi emosi untuk membantu mereka dalam mengatur emosi. Berbeda hal dengan Graziano dkk., (2007) yang meneliti keterampilan regulasi emosi dengan keberhasilan akademik anak. Anak-anak dengan keterampilan regulasi emosi yang lebih baik lebih mungkin untuk mendapatkan skor yang lebih tinggi untuk keberhasilan akademis atau produktivitas di dalam kelas; anak-anak dengan keterampilan regulasi emosi yang lebih baik diperoleh skor yang lebih tinggi pada ukuran standar matematika dan keterampilan membaca awal; anakanak dengan keterampilan regulasi emosi yang lebih baik memiliki masalah perilaku lebih sedikit dan memiliki hubungan yang lebih baik dengan para guru; dan anak-anak dengan keterampilan regulasi emosi yang baik, memungkinkan interaksi guru anak menjadi lebih positif.

Guru dapat mengajarkan regulasi emosi anak dengan cara menanggapi emosi dan mengajarkan tentang emosi. Guru memberikan bimbingan dalam kompetensi emosional dengan cara memodelkan emosi, menanggapi emosi anak, dan mengajarkan tentang emosi. Balzarotti dkk., (2016) meneliti strategi regulasi emosi kognitif yang ternyata efektif dalam mempromosikan kesejahteraan individu. Hasil penelitian menunjukkan bahwa penilaian yang positif dan fokus pada perencanaan berhubungan positif dengan subjektif dan kesejahteraan psikologis. Hasil ini juga menunjukkan bahwa strategi regulasi 
Jurnal PINUS: Jurnal Penelitian Inovasi Pembelajaran, 6 (1), 2020, Dema Yulianto, Hanggara Budi Utomo, dan Epritha Kurniawati

emosi kognitif efektif dalam mempromosikan kesejahteraan individu. Garnefski dkk., (2007) meneliti strategi regulasi emosi kognitif pada anak yang ditemukan berhubungan dengan gejala depresi, rasa takut dan khawatir pada anak. Penelitian ini menjelaskan beberapa sifat psikometrik dari CERQ - $\mathrm{k}$ dan hubungan dengan langkah-langkah depresi, rasa takut dan khawatir di antara 717 anak-anak. Strategi regulasi emosi kognitif ditemukan berhubungan dengan pelaporan data dari gejala depresi, rasa takut dan khawatir.

\section{KESIMPULAN}

Sebagaimana yang sudah diungkapkan dari kajian pembahasan, penelitian regulasi emosi secara kognitif selalu menghubungkan dengan hal-hal yang bersifat klinis, misalnya berhubungan dengan stress, gejala depresi, rasa takut, kecemasan, khawatir, dan lain-lain. Pendekatan kognitif menjelaskan bahwa emosi yang dirasakan individu merupakan hasil dari penilaian terhadap situasi yang dihadapinya. Individu yang menilai situasi yang dihadapi sebagai sesuatu yang positif akan mengembangkan response emosi yang positif pula, sebaliknya individu yang memberikan penilaian negatif terhadap situasi yang dihadapi akan mengembangkan emosi negatif pula. Peran regulasi emosi secara kognitif yang dapat dilakukan guru dalam menghadapi perilaku anti sosial anak usia TK, antara lain: (1) guru dapat mengajarkan regulasi emosi anak dengan cara menanggapi emosi dan mengajarkan tentang emosi; (2) guru dapat memberikan bimbingan dalam kompetensi emosional dengan cara memberikan contoh emosi yang positif dan negatif, cara menanggapi emosi anak, dan memanifestasikan emosi; (3) guru dapat berinteraksi dengan anak, sambil mengidentifikasi emosi yang sering muncul pada diri anak-anak.

\section{DAFTAR RUJUKAN}

Balzarotti, S., Biassoni, F., Villani, D., Prunas, A., \& Velotti, P. (2016). Individual differences in cognitive emotion regulation: Implications for subjective and psychological wellbeing. Journal of Happiness Studies, 17(1),

125-143. https://doi.org/10.1007/s10902-0149587-3

Burgess, L. M. (2006). Emotion regulation and behaviour, emotional and cardiovascular responses to interpersonal stress. An Arbor, MI:UMI.

Fried, L. (2011). Teaching teachers about emotion regulation in the classroom. Australian Journal of Teacher Education, 36(3), 117127. https://doi.org/10.14221/ajte.2011v 36n5.3

Garnefski, N., Kraaij, V., \& Spinhoven, P. (2001). Negative life events, cognitive emotion regulation and emotional problems. Personality and Individual Differences, 30(8), 1311-1327. https://doi.org/10.1016/S01918869(00)00113-6

Garnefski, Nadia, Rieffe, C., Jellesma, F., Terwogt, M. M., \& Kraaij, V. (2007). Cognitive emotion regulation strategies and emotional problems in 9-11-year-old children: The development of an instrument. European Child and Adolescent Psychiatry, 16(1), 1-9. 
Jurnal PINUS: Jurnal Penelitian Inovasi Pembelajaran, 6 (1), 2020, Dema Yulianto, Hanggara Budi Utomo, dan Epritha Kurniawati

https://doi.org/10.1007/s00787-0060562-3

Graziano, P. A., Reavis, R. D., Keane, S. P., \& Calkins, S. D. (2007). The role of emotion regulation in children's early academic success. Journal of School Psychology, 45(1), 3-19.

https://doi.org/10.1016/j.jsp.2006.0 9.002

Gross, J. J. (1998). The emerging field of emotion regulation: An integrative review. Review of General Psychology, 2(3), 271-299. https://doi.org/10.1037/10892680.2.3.271

Gross, J. J. (2002). Emotion regulation: Affective, cognitive, and social consequences. Psychophysiology, 39(3), 281-291. https://doi.org/10.1017/S004857720 1393198

Gross, J. J., Richards, J. M., \& John, O. P. (2007). Emotion regulation in everyday life. In Emotion regulation in couples and families: Pathways to dysfunction and health. (pp. 13-35). American Psychological Association. https://doi.org/10.1037/11468-001

John, E. (2011). Upaya meningkatkan kedisiplinan anak di kelas melalui cerita. Jurnal Pendidikan Penabur, 16(10).

Levenson, R. W. (1999). The intrapersonal functions of emotion. Cognition and Emotion, 13(5), 481-504. https://doi.org/10.1080/0269993993 79159

Strongman, K. T. (2003). The psychology of emotion: From everyday life to theory. In Wiley. Hoboken, NJ: Wiley.

Sugiyono. (2017). Metode penelitian kuantitatif, kualitatif, dan $R \& D$. Bandung: Alfabeta.
Sutton, R. E. (2004). Emotional regulation goals and strategies of teachers. Social Psychology of Education, 7(4), 379-398. https://doi.org/10.1007/s11218-0044229-y

Sutton, R. E., \& Wheatley, K. F. (2003). Teachers' emotions and teaching: a review of the literature and directions for future research. Educational Psychology Review, 15(4), 327-358. https://doi.org/10.1023/A:10261317 15856

Thompson, Ross; Calkins, S. (1996). The double-edged sword: Emotion regulation in high risk children. Development and Psychopathology, 8, 163-182.

Westen, D. (1994). Toward an Integrative Model of Affect Regulation: Applications to SocialPsychological Research. Journal of Personality, 62(4), 641-667. https://doi.org/10.1111/j.14676494.1994.tb00312.x

Yulianto, D., Yufiarti, \& Akbar, M. (2019). A study of cooperative learning and independence: Impact on children's prosocial behavior. International Journal of Educational, 12(1), 49-55. https://doi.org/10.17509/ije.v12i1.1 7522 